\title{
Enhanced sea-ice export from the Arctic during the Younger Dryas
}

Christelle $\operatorname{Not}^{1,2} \&$ Claude Hillaire-Marcel ${ }^{1}$

The Younger Dryas cold spell of the last deglaciation and related slowing of the Atlantic meridional overturning circulation have been linked to a large array of processes, notably an influx of fresh water into the North Atlantic related to partial drainage of glacial Lake Agassiz. Here we observe a major drainage event, in marine sediment cores raised from the Lomonosov Ridge, in the central Arctic Ocean marked by a pulse in detrital dolomitic-limestones. This points to an Arctic-Canadian sediment source area with about fivefold higher Younger Dryas ice-rafting deposition rate, in comparison with the Holocene. Our findings thus support the hypothesis of a glacial drainage event in the Canadian Arctic area, at the onset of the Younger Dryas, enhancing sea-ice production and drifting through the Arctic, then export through Fram Strait, towards Atlantic meridional overturning circulation sites of the northern North Atlantic.

\footnotetext{
${ }^{1}$ GEOTOP, Université du Québec à Montréal, C.P. 8888 Succ. Centre-Ville, Montréal, Quebec H3C 3P8, Canada. ${ }^{2}$ Department of Ocean Floor Geosciences, Atmosphere and Ocean Research Institute, University of Tokyo, Kashiwa 277-8564, Japan. Correspondence and requests for materials should be addressed to C.H.-M. (chm@uqam.ca).
} 
T he Last Glacial Maximum (LGM) was followed by a deglaciation sequence punctuated by millennial-scale events, notably Heinrich Event 1 and the Younger Dryas (YD). It is now generally accepted that both involved a significant reduction in the Atlantic meridional overturning circulation (AMOC) attributed to enhanced meltwater inputs into the North Atlantic ${ }^{1,2}$. The YD, spanning $\sim 12,800$ to $\sim 11,700$ cal years $\mathrm{BP}^{3,4}$ corresponds to a period of cold conditions within the general climate warming that occurred during the transition from the LGM to the Holocene ${ }^{5,6}$. Of a large array of potential trigger mechanisms of the YD event that have been put forth ${ }^{5-7,8}$, the most widely supported scenario involves a major drainage pulse from glacial Lake Agassiz ${ }^{7}$, which surrounded the southwestern sector of the Laurentide Ice Sheet (LIS). A debate persists with respect to the drainage route, either eastward, through the Great Lakes-St Lawrence system or, northward, through the Mackenzie River delta ${ }^{9-15}$. However, high-resolution model experiments by Condron and Winsor ${ }^{16}$ suggest that any meltwater pulse and/or re-routing from these eastern and southeastern continental outlets would be dispersed into the subtropical
North Atlantic, with a subsequently limited influence on the AMOC sites. In addition, Murton et al. ${ }^{17}$ provided evidence for drainage of Lake Agassiz, through the Mackenzie River delta, during the critical time interval. Optically stimulated luminescence measurements in aeolian sands interbedded with coarse fluvial material, assigned to drainage pulses, yielded ages compatible with a YD assignment. These findings strongly support the northward route scenario originally advanced by Tarasov and Peltier ${ }^{11}$ and further discussed by Teller and Boyd ${ }^{18}$. Polyak et al. ${ }^{19}$ also invoked this Arctic trigger scenario, based on a sedimentary record from the Chukchi margin. However, only one single ${ }^{18} \mathrm{O}$ depleted value supports the extension of their record into the YD interval, not to mention uncertainties about the age model, because of an open debate about the reservoir age correction for Arctic Ocean palaeowaters. Thus no clear 'marine' evidence for a major drainage event in the Canadian Arctic, at the onset of the YD, has yet been found.

Here we present evidence for such a drainage event, based on detailed sedimentological and geochemical investigations on a multicore and a trigger-weight core (henceforth MC-18 and
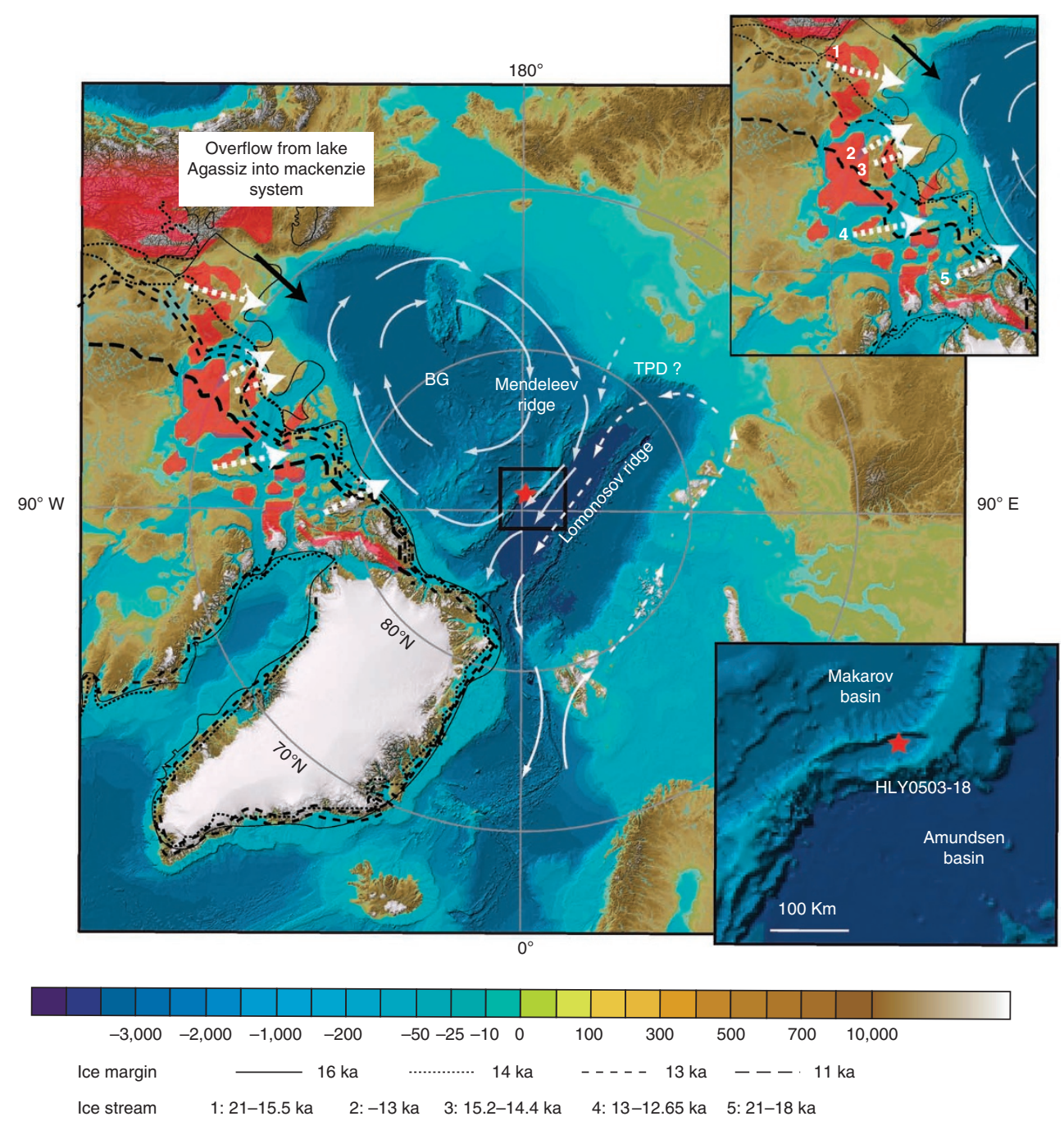

Figure 1 | Core location and geographical distribution of carbonates in Canadian Arctic region. The coring site HLY0503-18 is located on the Lomonosov Ridge in the central Arctic. Bathymetry is from the International Bathymetric Chart of the Arctic Ocean ${ }^{30}$. Mineralogical sources of calcite and dolomite (red areas) are indicated based on Phillips and Grantz ${ }^{24}$ and the geological map of Canada. Palaeo-ice margins (black line) of the Laurentide Ice Sheet at 16,14, 13 and $11 \mathrm{ka}$ are represented with black line, and palaeo-ice streams are represented by white dashed arrows; approximate age are shown at the bottom of the figure, based on Dyke ${ }^{31}$ and Stokes and Tarasov ${ }^{25}$. The Agassiz drainage route described by Murton et al. ${ }^{17}$ is indicated by the black arrow. Surface currents and sea-ice routes are represented by white arrows. We hypothesize an enhanced Beaufort Gyre (BG) during the Lake Agassiz drainage event through the Mackenzie area at $\sim 13$ to $12 \mathrm{ka} \mathrm{BP}$. 
TC-18) taken from a Lomonosov Intrabasin, in the central Arctic, at a water depth of $\sim 2,500 \mathrm{~m}$ (Fig. 1). Our data demonstrate enhanced transport of sea ice from Canadian Arctic source, in the central Arctic, and its export through Fram Strait to the North Atlantic.

\section{Results}

Chronology. An age model based on eleven radiocarbon analyses on planktic foraminifer from TC-18, has been proposed by Hanslik et al. ${ }^{20}$ High-resolution ${ }^{210} \mathrm{~Pb}$ data allowed us to carry over this age model to MC-18 as illustrated in Figure 2. The sedimentation rate is estimated to be $1.7 \mathrm{~cm} \mathrm{ka}^{-1}$ during the Holocene. From $\sim 22$ to $\sim 33 \mathrm{~cm}$ downcore, all ages fall into the range $\sim 12-13$ cal ka BP, indicating a substantial increase in the rate of sedimentation during that period, combined with a ${ }^{14} \mathrm{C}$-plateau ${ }^{21}$, which we attribute to the YD. Deeper in the core, two ages of almost 30 calka BP indicate a late Marine isotope stage (MIS) 3 assignment for the lower part of the section. The hiatus matching broadly the MIS 2 interval indicates either a near complete cessation of sediment supply, or its removal through erosion. Erosion seems improbable, because the coring site is located in a small intraridge basin. Thus, we interpret the abrupt jump from $\sim 27$ to $\sim 13 \mathrm{cal}$ ka BP (between $\sim 34$ and $\sim 33 \mathrm{~cm}$ downcore in MC-18) as an indication of a near-complete cessation of sedimentation, thus of ice-rafting deposition, during MIS 2. This MIS 2-hiatus in sedimentation is also observed elsewhere in the central Arctic ${ }^{22}$ and suggests reduced sea-ice mobility along the Beaufort Gyre and Transpolar Drift routes.

Sedimentary and geochemical features. A closer look at sedimentary and geochemical features allows the identification of the source and mechanism leading to the dispersal of detrital carbonates to the remote Lomonosov Ridge area during the subsequent YD interval. In the corresponding layer (Fig. 3), carbonates are mainly composed of $50 \%$ calcite and $50 \%$ dolomite, which both increase in the silt and sand fractions (Fig. 3). Such pulses of detrital, dolomite-rich carbonates are linked to the dispersal, off the LIS margin, of glacial sediments originating from Lower Palaeozoic bedrock areas, in the Canadian Arctic ${ }^{23,24}$. Palaeozoic carbonate rocks outcrop on Victoria Island, in the southern part of the Canadian Arctic Archipelago and in the Mackenzie Valley (based on the Canada Bedrock map, shown in Fig. 1). Three mechanisms can introduce detrital carbonates from these sources into the deep Arctic Ocean: erosion of carbonate glacial drift by melt water in the Mackenzie River drainage basin ${ }^{17}$; density currents from LIS runoff along its northern margin; and ice-rafting from palaeo-ice streams (for example, from M'Clure Strait, carrying Silurian carbonate material from the NE Canadian margin ${ }^{25}$ ). Enhanced ice-rafting from the eastern part of the Canadian Arctic Archipelago seems unlikely, as indicated by ice margin and ice stream palaeogeography at the onset of the YD (Fig. 1). Moreover, a major peak in ${ }^{230} \mathrm{Th}$-excess $\left({ }^{230} \mathrm{Th}_{\mathrm{xs}}\right)$ matches this carbonate pulse, suggesting a strong influx of scavenging (thus relatively fine) particles (Fig. 3 ). This excess, well above ${ }^{230} \mathrm{Th}$ production by dissolved-U from the overlying water column, corresponds to a ${ }^{230} \mathrm{Th}_{\mathrm{xs}}$ flux about five times the mean Holocene flux (Fig. 3). It indicates similarly enhanced fluxes of scavenging particles, in the sea-ice production areas, and supports the scenario of the long-distance ice-rafting dispersal of fine particles from the drainage event. Immediately above the corresponding sedimentary pulse, ${ }^{230} \mathrm{Th}_{\mathrm{xs}}$ decreases to its production in the overlying water column, thus indicating a drop in the sedimentary supply of scavenging particles. Later on, during the Holocene, ${ }^{230} \mathrm{Th}_{\mathrm{xs}}$ exceeding the overlying water column production is observed again, but with fluxes well below those highlighting the sedimentary pulse of the YD (Fig. 3), a fact highlighting the singularity of the YD-event in the record.

\section{Discussion}

The above sedimentary features suggest a pulse in ice-rafted debris, at the study site, linked to enhanced sea-ice production and drifting from the Canadian Arctic area. A major drainage event from the LIS margin, the most plausible candidate indeed being here Lake Agas$\operatorname{siz}^{17}$, is seen as the trigger of this pulse in sea-ice production and export. Any northern drainage of Lake Agassiz, during this interval, had to occur in the corridor between the Cordilleran Ice Sheet and the LIS. Off the drainage outlet, such a meltwater pulse would have enhanced the production of sea ice 'labelled' by detrital particles carrying a mineralogical signature (dolomite) from the area. Seaice export through the central Arctic, through the Beaufort Gyre

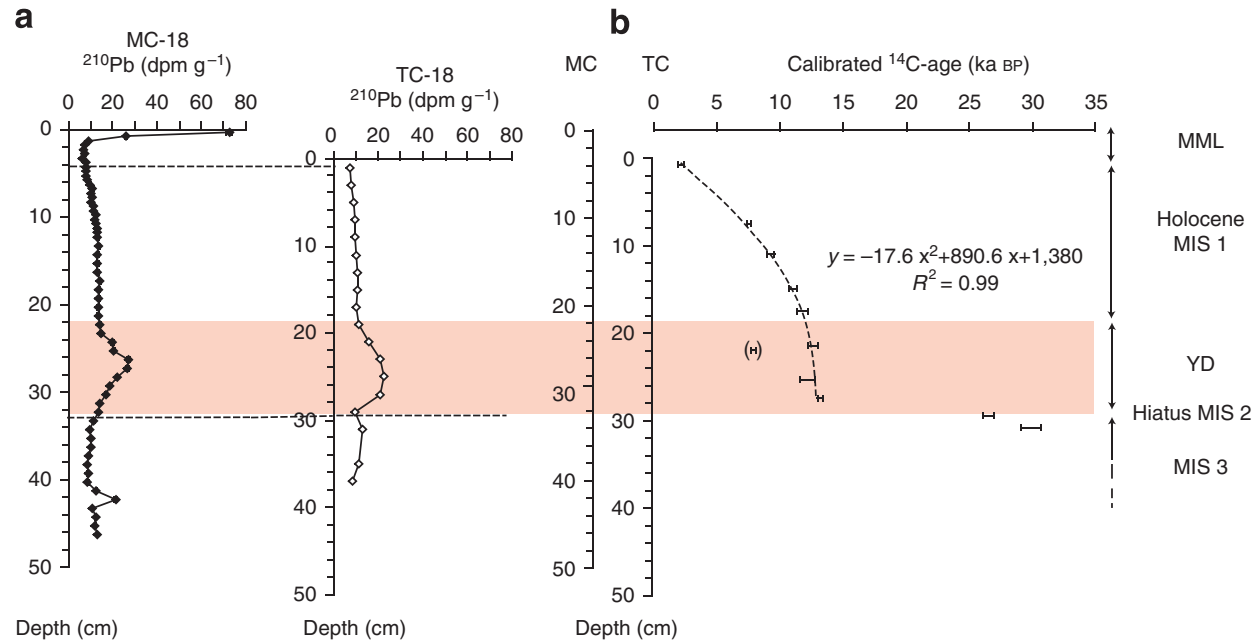

Figure 2 | Core age model. (a) Correlation between TC-18 and MC-18 based on ${ }^{210} \mathrm{~Pb}$ data. (b) Chronology of MC-18 based on the age model of Hanslik et al. ${ }^{20}$ and ${ }^{210} \mathrm{~Pb}$ correlation. The first three centimetres in $\mathrm{MC}-18$ correspond to the modern mixed layer (MML; missing in TC-18). Down to $22 \mathrm{~cm}$, the ${ }^{14} \mathrm{C}$

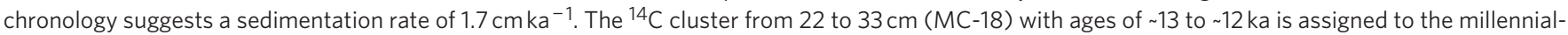
scale event of the YD age. Below $33 \mathrm{~cm}$, the sequence indicates reduced sedimentation rates or even a hiatus during the LGM. ${ }^{14} \mathrm{C}$-ages suggest a late MIS 3 assignment for sediments deposited before the YD event. The ${ }^{14} \mathrm{C}$-outlier at $25 \mathrm{~cm}$ in MC-18 (bracketed), unexplained in Hanslik et al. ${ }^{20}$, might be due to a non-local mixing event or a sampling artefact. Note the slight compaction with some smoothing of $210 \mathrm{~Pb}$-activities in TC-18 compared with MC-18. The ${ }^{210} \mathrm{~Pb}$-peak assigned to the YD event matches a peak of parent ${ }^{230} \mathrm{Th}$, whereas the top- $1 \mathrm{~cm}$ peak in $\mathrm{MC}-18$ relates mostly to the mixing of ${ }^{210} \mathrm{~Pb}$-rain produced in the water column during the last 100 years. 


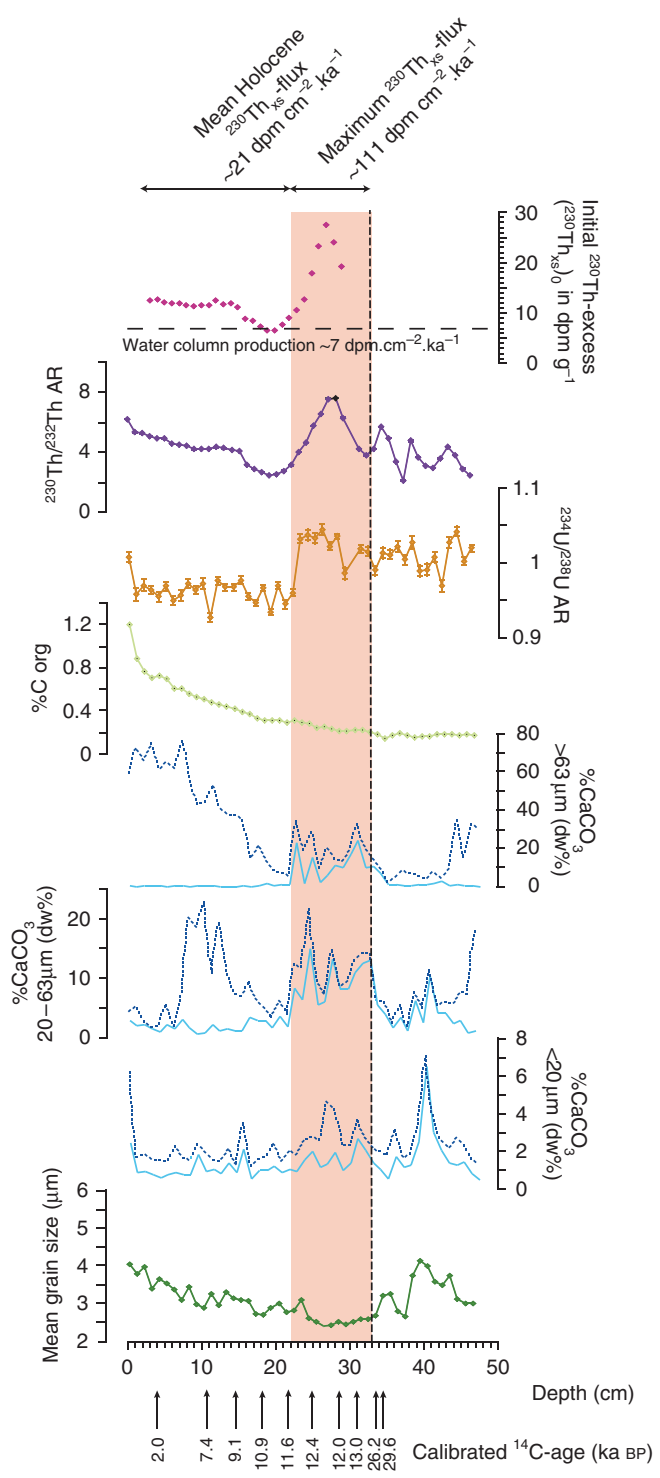

Figure 3 | Geochemical and sedimentological data for core HLY050318MC. ${ }^{230} \mathrm{Th}_{\mathrm{xs} \mathrm{O}},{ }^{230} \mathrm{Th} /{ }^{232} \mathrm{Th}$ and ${ }^{234} \mathrm{U} /{ }^{238} \mathrm{U}$ are respectively represented in pink, purple and orange. The mean grain size is represented in dark green, the organic carbon content in light green, dolomite and calcite are respectively in light and dark blue for all size fractions. The initial excess of ${ }^{230} \mathrm{Th}\left({ }^{230} \mathrm{Th}_{\mathrm{xs} 0}\right.$ ) illustrated on top, represents the ${ }^{230} \mathrm{Th}$ produced through dissolved- ${ }^{234} \mathrm{U}$ decay in the water column and scavenged by sinking particles. It is calculated as the ${ }^{230} \mathrm{Th}$ in excess over the fraction supported by ${ }^{234} \mathrm{U}$, in the sediment, with correction for radioactive decay since deposition. The horizontal dashed-line illustrating the ${ }^{230}$ Th-production in the overlying water column is calculated on the basis of Suman and Bacon $^{32}$. The peak in ${ }^{230} \mathrm{Th}_{\mathrm{xs} O}$ during the YD indicates a large particle influx and focusing at the coring site. The YD interval is also highlighted by a subsequent drastic change in the ${ }^{234} \mathrm{U} /{ }^{238} \mathrm{U}$ activity ratio linked to distinct sediment sources; this unit is also characterized by its relatively high dolomite content in the silt and sand fractions, pointing to an Arctic-Canadian source for the detrital supplies.

and then the Transpolar Drift, carried this signature as far as the Lomonosov Ridge, and had to result in an increase rate of sea-ice export through Fram Strait into the Greenland-Iceland-Norwegian seas and the North Atlantic.

Also noteworthy is the fact that the end of YD interval $(22 \mathrm{~cm}$ downcore MC-18) is marked by a major change in ${ }^{234} \mathrm{U} /{ }^{238} \mathrm{U}$ activity ratios (Fig. 3). Above, ${ }^{234} \mathrm{U}$ is in deficit versus its parent ${ }^{238} \mathrm{U}$, as is often observed in oxidized sub-surface sedimentary lay$\mathrm{ers}^{26}$, whereas below, near-equilibrium conditions prevail between the two isotopes. This suggests a change in sediment source and/or accumulation rate ${ }^{27}$. Because the ${ }^{234} \mathrm{U}$-excess persists deeper in the core through the layer assigned to MIS 3, without being affected by their drastic difference in sedimentation rates, a change in sediment source seems more likely, following the YD. Here the possibility of a diagenetic uptake of uranium from sea water related to lower redox conditions is rejected since the organic carbon content is practically unchanged on both sides of this transition ${ }^{28}$. The change in sedimentary sources at the end of the YD interval suggests changes in the area of sea-ice production transporting sediment to the Lomonosov Ridge. During MIS 3 and the YD, the geochemical signature (presence of dolomite and high ${ }^{234} \mathrm{U} /{ }^{238} \mathrm{U}$ ratio) of Canadian margin material suggests a prominent influence of seaice from the Canadian Arctic with an active Beaufort Gyre (Fig. 1). The absence of dolomite in the different size fractions during the Holocene, then suggests a significant reduction of Canadian sources and a dominant influence of material from Russian sources through direct Transpolar Drift supplies (see also ref. 20).

On the basis of the Lomonosov ridge record, a drainage event with an Arctic-Canadian signature, at the onset of the YD is proposed. Earlier, Peltier et al. ${ }^{29}$ and Peltier ${ }^{6}$, demonstrated that such a northern route for a freshwater pulse (through sea-ice export), likely linked to Lake Agassiz drainage accompanying some collapse of the Keewatin Dome of the LIS, would have been as efficient in 'shutting down' the AMOC. The hiatus matching MIS 2 (the last glacial maximum sensu lato), suggests a complete interruption of sedimentation in the area, thus a sluggish Transpolar Drift (if any), with a thick pack ice occupying the central Arctic.

The resumption of the sea-ice transport in the Central Arctic, due to the drainage event would have been responsible for enhanced sea-ice export through Fram Strait into the Nordic Seas, resulting in a slow-down of the AMOC. However, we must admit that inherent uncertainties of the marine ${ }^{14} \mathrm{C}$ chronology at the Allerød-YD transition added to poorly constrained ${ }^{14} \mathrm{C}$-reservoir ages of Arctic waters, makes impossible to unequivocally identify the trigger mechanism responsible of the YD from such records.

\section{Methods}

Study sites. Core HLY0503- 18 TC $\left(88^{\circ} 27^{\prime} \mathrm{N} ; 146^{\circ} 34^{\prime} \mathrm{E} ; 2,598 \mathrm{~m}\right.$ water depth, $117.8 \mathrm{~cm}$ in length) and core HLY0503-18 MC ( $88^{\circ} 26^{\prime} \mathrm{N} ; 146^{\circ} 41^{\prime} \mathrm{E} ; 2,654 \mathrm{~m}$ water depth, $47 \mathrm{~cm}$ in length) were retrieved in Lomonosov intrabasin during the HOTRAX 2005 expedition.

Age model. The age model used in this study is the age model published in Hanslik et al. ${ }^{20}$ transposed from TC-18 to MC-18 based on ${ }^{210} \mathrm{~Pb}$ profiles. Hanslik et al. ${ }^{18}$ obtained eleven accelerator mass spectrometry ${ }^{14} \mathrm{C}$ ages on tests of planktic foraminifer assemblages (Neogloboquadrina pachyderma). These ${ }^{14} \mathrm{C}$ ages were calibrated using the Marine04 data set in OxCal 4.0 (with a 95\% confidence interval). A $\Delta R=300$ was applied on ${ }^{14} \mathrm{C}$ age from 0 to $16 \mathrm{~cm}$, whereas $\Delta R=1,000$ was applied deeper based on foraminifera abundances, as discussed in Hanslik et al. ${ }^{20}$ Errors are 2 s.d. Two ${ }^{14} \mathrm{C}$ ages, deeper in the core, yielded ages beyond the $\mathrm{OxCal}$ calibration range. The Fairbanks0107 calibration curve was then used and the error corresponds to 1 s.d. (see Hanslik et al..$^{20}$ for details).

U-series isotopes analysis. Lead-210 isotopes were measured by alpha counting; uranium and thorium isotopes by multi-collector-inductively coupled plasma-mass spectrometry on bulk sediment. Initial ${ }^{230} \mathrm{Th}$-excess values $\left({ }^{230} \mathrm{Th}_{\mathrm{xs} 0}\right)$ in the deglacial to Holocene sections were simply calculated by subtracting ${ }^{234} \mathrm{U}$-activities, and correcting for decay based on interpolated ages from calibrated ages.

Sediment properties analysis. Particle-size fractions were determined using a laser-diffraction particle-size analyser (LS13320 Beckman-Coulter) on bulk sediment, and grain-size statistics were processed with the Gradistat program. The silt fraction corresponds to the size fraction between 2 and $63 \mu \mathrm{m}$. Mineralogical assemblages were determined by X-ray diffraction using a Siemen D5000 with CoKo1,2 radiation and a Si detector. Semi-quantitative estimations $( \pm 1 \sigma \sim 5 \%)$ of the main mineral species were based on the area of the diffraction peak for each mineral corrected for quartz. The calcite and dolomite contents 
were measured in several fractions, including the $>63 \mu \mathrm{m}$ fraction, characteristic of ice-rafted sediment in deep-water marine environments. The organic carbon (Corg) content was determined by the acidification of total sediment with $\mathrm{HCl} 1 \mathrm{~N}$ and elemental-C analysis of the residual fraction with a Carlo Erba elemental analyzer. Further details about methods can be found in Not and Hillaire-Marcel22.

\section{References}

1. Clark, P. U. et al. Freshwater forcing of abrupt climate change during the last glaciation. Science 293, 283-287 (2001).

2. McManus, J. F., Francois, R., Gherardi, J. M., Kelgwin, L. \& Drown-Leger, S. Collapse and rapid resumption of Atlantic meridional circulation linked to deglacial climate changes. Nature 428, 834-837 (2004).

3. Muscheler, R. et al. Tree rings and ice cores reveal ${ }^{14} \mathrm{C}$ calibration uncertainties during the Younger Dryas. Nature Geosci. 1, 263-267 (2008).

4. Walker, M. et al. Formal definition and dating of the GSSP (Global Stratotype Section and Point) for the base of the Holocene using the Greenland NGRIP ice core, and selected auxiliary records. J. Quat. Sci. 24, 3-17 (2009).

5. Broecker, W. S. Was the Younger Dryas triggered by a flood? Science 312, 1146-1148 (2006)

6. Peltier, W. R. Rapid climate change and Arctic Ocean freshening. Geology 35, 1147-1148 (2007)

7. Carlson, A. E. What caused the Younger Dryas cold event? Geology 38, 383-384 (2010).

8. Broecker, W. S. et al. Putting the Younger Dryas cold event into context. Quat. Sci. Rev. 29, 1078-1081 (2010).

9. Broecker, W. S. et al. Routing of meltwater from the Laurentide Ice sheet during the Younger-Dryas cold episode. Nature 341, 318-321 (1989).

10. de Vernal, A., Hillaire-Marcel, C. \& Bilodeau, G. Reduced meltwater outflow from the Laurentide ice margin during the Younger Dryas. Nature 381, 774-777 (1996).

11. Tarasov, L. \& Peltier, W. R. Arctic freshwater forcing of the Younger Dryas cold reversal. Nature 435, 662-665 (2005).

12. Peltier, W. R., de Vernal, A. \& Hillaire-Marcel, C. Geology 36, e178 (doi:10.1130/G24971Y.1) (2008).

13. Carlson, A. E. \& Clark, P. U. Geology 36, el77 (doi:10.1130/G24786C.1) (2008)

14. Cronin, T. M., Rayburn, J. A., Guilbault, J. P., Thunell, R. \& Franzi, D. A. Stable isotope evidence for glacial lake drainage through the St Lawrence Estuary, eastern Canada, 13.1-12.9ka. Quat. Int. (doi:10.1016/j.quaint.2011.08.041) (2011).

15. Rayburn, J. A., Cronin, T. M., Franzi, D. A., Knuepfer, P. L. K. \& Willard, D. A. Timing and duration of North American glacial lake discharges and the Younger Dryas climate reversal. Quat. Res. 75, 541-551 (2011).

16. Condron, A. \& Winsor, P. A subtropical fate awaited freshwater discharged from glacial Lake Agassiz. Geophys. Res. Lett. 38, L03705 (2011).

17. Murton, J. B., Bateman, M. D., Dallimore, S. R., Teller, J. T. \& Yang, Z. Identification of Younger Dryas outburst flood path from Lake Agassiz to the Arctic Ocean. Nature 464, 740-743 (2010).

18. Teller, J. T. \& Boyd, M. Two possible routings for overflow from Lake Agassiz during the Younger Dryas. Quat. Sci. Rev. 25, 1142-1145 (2006).

19. Polyak, L., Darby, D., Bischof, J. \& Jakobsson, M. Stratigraphic constraints on late Pleistocene glacial erosion and deglaciation of the Chukchi margin, Arctic Ocean. Quat. Res. 67, 234-245 (2007).

20. Hanslik, D. et al. Quaternary Arctic Ocean sea ice variations and deep water isolation times. Quat. Sci. Rev. 29, 3430-3441 (2010).

21. Broecker, W. S. Defining the boundaries of the late-glacial isotope episodes. Quat. Res. 38, 135-138 (1992).
22. Not, C. \& Hillaire-Marcel, C. Time constraints from ${ }^{230} \mathrm{Th}$ and ${ }^{231} \mathrm{~Pa}$ data in Late Quaternary, low sedimentation rate sequences from the Arctic Ocean: an example from the northern Mendeleev Ridge. Quat. Sci. Rev. 29, 3665-3675 (2010).

23. Bischof, J., Clark, D. L. \& Vincent, J. S. Origin of ice-rafted debris: Pleistocene paleoceanography in the western Arctic Ocean. Paleoceanography 11, 743-756 (1996).

24. Phillips, R. L. \& Grantz, A. Regional variations in provenance and abundance of ice-rafted clasts in Arctic Ocean sediments: implications for the configuration of late Quaternary oceanic and atmospheric circulation in the Arctic. Mar. Geol. 172, 91-115 (2001).

25. Stokes, C. R. \& Tarasov, L. Ice streaming in the Laurentide Ice sheet: a first comparison between data-calibrated numerical model output and geological evidence. Geophys. Res. Lett. 37, L01501 (2010).

26. Barnes, C. E. \& Cochran, J. K. Uranium removal in oceanic sediments and the oceanic U balance. Earth Planet. Sci. Lett. 97, 94-101 (1990).

27. Klinkhammer, G. P. \& Palmer, M. R. Uranium in the oceans: where it goes and why. Geochim. Cosmochim. Acta 55, 1799-1806 (1991).

28. Gariepy, C., Ghaleb, B., Hillaire-Marcel, C., Mucci, A. \& Vallieres, S. Early Diagenetic Processes in Labrador Sea Sediments-Uranium-Isotope Geochemistry. Can. J. of Earth Sci. 31, 28-37 (1994).

29. Peltier, W., Vettoretti, G. \& Stastna, M. Atlantic meridional overturning and climate response to Arctic Ocean freshening. Geophys. Res. Lett. 33, L06713 (2006).

30. Jakobsson, M. et al. An improved bathymetric portrayal of the Arctic Ocean: Implications for ocean modeling and geological, geophysical and oceanographic analyses. Geophys. Res. Lett. 35, L07602 (2008).

31. Dyke, A. S. in Quaternary Glaciations-Extent and Chronology, Part II: North America, Dev. Quat. Sci. (eds Ehlers, J. \& Gibbard, P. L.) 373-424 (Elsevier, 2004).

32. Suman, D. O. \& Bacon, M. P. Variations in Holocene sedimentation in the North American Basin determined from ${ }^{230} \mathrm{Th}$ measurements. Deep Sea Res. Part A. 36, 869-878 (1989).

\section{Acknowledgements}

This study, initiated within the Polar Climate Stability Network program (Canadian Foundation for Climate and Atmospheric Sciences), has been completed through support from the Ministère du Développement économique, de l'innovation et de l'exportation of Québec to the Past4Future research initiative. Funding from the Natural Sciences and Engineering Research Council and the Fonds Québecois de la Recherche sur la Nature et les Technologies (GEOTOP grant and team grant to de Vernal et al.) is also acknowledged. Support from GEOTOP members has been essential for the achievement of the exhaustive analytical program behind this study, with particular thanks to Bassam Ghaleb and Michel Preda.

\section{Author contributions}

C.N. performed the U-series isotope measurements. C.N. and C.H.-M. interpreted the results and wrote the manuscript.

\section{Additional information}

Competing financial interests: The authors declare no competing financial interests.

Reprints and permission information is available online at http://npg.nature.com/ reprintsandpermissions

How to cite this article: Not, C. \& Hillaire-Marcel, C. Enhanced sea-ice export from the Arctic during the Younger Dryas. Nat. Commun. 3:647 doi: 10.1038/ncomms1658 (2012) 